\title{
ECONOMIC POLICY OF GROWTH: SELECTION OF INSTITUTES AND TECHNOLOGICAL MODELS OF DEVELOPMENT
}

\author{
Oleg SUKHAREV(D)1, Vladimir CHAPLYGIN (iD)2* \\ ${ }^{I}$ Institute of Economics of the Russian Academy of Sciences, 32 Nakhimovsky Prospect, 117248, Moscow, Russia \\ ${ }^{2}$ Institute of Economy and Management, Immanuel Kant Baltic Federal University, \\ 14 A. Nevskogo str., 236016, Kaliningrad, Russia \\ EE-mail: rusbanker@mail.ru
}

\begin{abstract}
Purpose - to study the possibilities of institutional theory to establish a modern theory of economic growth, including the factors of institutions and technologies changes. These factors are a set of rules with high coercive force to the agents' action form a particular mode/model of their adaptation, together with other institutions.

Research Methodology - the neoclassical models of economic growth, which may include institutional factors and to study their impact on the growth and change of the factors, into the business practice are applied. The key scientific problem is to choose the right market Institute for a proper way of technological development. The authors use the micro-level analysis of the agents and institutions' interaction in the process of new technologies appearance. Morphological and taxonomic analysis in order to highlight the models of technological development and economic growth had been applied.
\end{abstract}

Findings - the research results may enrich an economic theory and practice in the area of business models applicability. The findings may assist a business community to influence the general technological development within the national institutional systems.

Research limitations - due to the fact that different institutions, structures and technologies act on the economic dynamics at the same time, separating their influence is an independent scientific problem that is not solved in all cases. However, the set of considered institutional factors forms and provides a kind of "manufacturability" of economic growth.

Practical implications - the so-called institutional macroeconomics as a practical discipline (which has a very close connection with behavioural macroeconomics) may assist to explore the economic growth from the point of view of changing institutions (firms, business community), labour markets and information - technical and technological changes.

Originality/Value - the value of the research consists in the systematization of institutional factors affecting the economic growth, conducting a morphological structural analysis of growth types, which allow identifying eight main growth trajectories in business activity.

Keywords: institutional theory, economic change, economic growth factors, models, technologies, institutions adaptation, business practice.

JEL Classification: B15, B25, B52, C51, D02, E02, O11, O33, O43.

Conference topic: Contemporary Issues in Economics Engineering.

\section{Introduction}

There are two main branches of the research in institutional theory: the study of institutions and institutional changes and the study of technologies and technological changes. According to Veblen (Veblen, 1980, 2007), customs and stereotypes of thinking, which refer to the major part of the society, are considered to be institutions. According to North (North, 2010) institutions are game rules including formal and informal limitations and compulsion to fulfil the former and the latter. The detailed and evasive definition is given by Menard. In his opinion institution is a complex of social and economic rules functioning in a certain historical period over which individuals or groups of individuals have no power both in short-term and medium-term periods. From the economic viewpoint, these rules are aimed to define the conditions under which individual or collective choice of resources allocation and use can be 
made. Differentiating institutions, markets and organizations he insists that institutions are not coordination mechanisms, but they "aid to define social-historical conditions under which these mechanisms can form" (Menard, 1996).

In the framework of modern approaches in the theory of economic growth, the features of the influence on the economic dynamics of various factors are studied, with an emphasis on the factor of scientific and technological progress and technological changes. We'd focused upon the institutional and technological factors of economic growth, using the accumulated knowledge within the framework of the modern growth theory (Alonso-Carrera \& Raurich, 2018; Gabardo, Pereima, \& Einloft, 2017; Samaniego \& Sun, 2016; Brancaccio, Garbellini, \& Giammetti, 2018; Iamsiraroj, 2016; Felice, 2016; Aguirre, 2017; Bartolini \& Santolini, 2017; Balachandran \& Williams (2018), to show the individual problems and unresolved issues. An urgent task in relation to the current situation is to justify the policy of economic growth and in conjunction with the theoretical developments that economics has today. Particular emphasis was placed on the demonstration of various possible regimes and types of economic growth, based on the assumption of the technological function of the economic system, which predetermines possible strategies not only for scientific and technological development but also for economic growth.

\section{Theoretical background}

In modern conditions, the theory of economic growth has undergone significant changes, which deal with different development factors and development conceptions. The development conceptions assume the achievement of economic, social and technological goals. A new knowledge, human capital and technological development become the main factors of economic growth.

Recently, there has been an increase in the number of studies on economic development and growth, a number of researchers believe that it is economic growth that makes it possible to achieve the main goals of the economy, including an increase in the average per capita income of citizens. However, today there is a significant differentiation of opinions about the identity of the concepts of economic development and growth (Hartwell, 2016; Aguirre, 2017, etc.). In the works of one group of authors traced the view of the synonyms of these concepts (Iamsiraroj, 2016). Another group adheres to an opposite opinion (Vo \& Le, 2017; Ryser, Halseth, Markey, \& Morris, 2016). Some scholars express views that differ from the positions of both groups (Balachandran\& Williams, 2018). Balachandran B., Williams B., for example, put forward the thesis that "...economic development is a special type of economic growth". At the same time, all authors are unanimous in the importance of studying economic growth as "goals and criteria for creating the material basis for the prosperity of a socio-economic society" (Felice, 2016). On the other hand, some scientists emphasize that "... economic growth does not solve a number of social problems" (Yang \& Jung, 2016). Meanwhile, the current study is necessary for improving the already existing economic theories.

The authors systematize the main institutional factors of economic growth policy by highlighting the technological development regimes which describe the trajectories of modern economic growth, where technology plays the key role. By using a taxonomic research method and morphological analysis of the structural elements of the economic system, which allows establishing the presence of one or another type of growth and technological development, we'd highlighted the development trajectories for the three main components: natural resource, scientific and technical, and institutional with the release of the economic growth model inherent in the economic system.

\section{The study of economic changes and growth \& research methodology}

Economic growth is carried out by a system of elements, and the set of these elements and their coherent dynamics influence the total growth rate of the economy. In this case, there is a change in the composition of the elements of the economy, the laws of their connection. This changes the economic structure and quality of economic growth. In this regard, the method of analyzing the growth trajectory can be a structural analysis, as well as a morphological one. Considering that the rules of economic behaviour also change permanently, having a significant impact on the behaviour of agents, institutional conditions are highly relevant in the study of growth problems and the formation of economic growth policies. The natural resource factor by itself also determines the growth potential, as well as the accumulated scientific and technical reserves that set the mode of technology change and affect the technological efficiency of the economy.

Veblen considered, that the principal factor providing economic development is the conflict between monetary sector, industry financing and the industry itself, between monetary and industrial culture. So initially representatives of institutional approach saw its practical application in the use of this theory in studying the problems of industrial organizations development. The works of Nelson, Winter, Cantner, Hanush, Silverberg and Verspagen confirm this tendency (Nelson \& Winter, 2000; Cantner \& Hanusch, 2002; Nelson, 2008; Silverberg \& Verspagen, 1995; Williamson, 1975). 
As far back as 1918, Hamilton asserted in his speech, that institutionalism is practically the only theory, which can unite economic science (presented by isolated doctrines at that time) because it shows how separate parts of economic system correlate with the whole. Neoclassical doctrines (mainstream school) which covered the theory of the general balance of Walras and A. Marshall's "partial equilibrium" in the local markets, neglected the influence which institutions exerted on economy functioning (Blaug, 1994). The difference between the content of the mainstream research program and the institutional economy was in the fact that exchange and procedures connected with it acted as endogenous variables in the "mainstream" and production engineering, individual tastes were treated as exogenous variables specified for the given conditions for a long time. Thus tastes were assumed as stable - the "independence" principle of the consumer was beyond any doubt. The principle of "balance" and the abstractdeductive approach of knowledge of economic reality predominated. In institutional economy production, engineering and individual tastes and preferences are endogenous variables. They change in common in the course of changes in public relations, decision-making and operations in production and exchange. The only environment acts as an exogenous "variable" (Hodgson 2003, 2006).

Positioning institutionalism in the form of two schools - old and new ones (Williamson, 1975) defined a "certain dichotomy in the field of researches of institutions and technologies". On the one hand, old institutionalists had a tradition to describe the role and importance of engineers, industrial organization and industrial system (new industrial and postindustrial) in economic development singling out the role of institutions and operating social structures. On the other hand, a new branch of institutionalism, headed by Coase, bricked up the research efforts concerning industrial organization and branch structure of economy subject to the influence on these changes of the property rights and transactional costs (Coase, 2000, 1993).

Certainly, initial resources and knowledge availability is a basic condition for development. And whatever institutions could have been created, but without due competences, technological knowledge and resources high social standard of living could have hardly been achieved. Moreover, shortage of the listed components would not allow creating necessary institutions because institutional planning and possibilities of institutions perfection are also defined by the level of knowledge, technological development and resource provision.

From the moment of its origination institutionalism assumed evolutionary approach. Program requirements of early institutionalism according to Homan (Homan, 1932), were the following:

1) underlining of change phenomenon (Later on North (North, 2010) and others institutionalists, J. Hodgson, in particular, paid attention to the factors of economic changes and to the necessity of working out of the theory of economic changes);

2) negation of regular (neoclassical - author's comment) theory because of its inaccuracy and isolation from management problems;

3) consideration of management mechanism as a basic appendix of economic theory;

4) substantiation of descriptive (inductive - author's comment) method and quantitative researches.

Today it is possible to allocate some directions where institutional theory can get useful results in the field of changes and economic growth study:

- innovations and technologies - working out of scientific and technical and industrial policy, on the basis of the combination of analysis achievements on micro and macro levels in spite of the fact that institutional macroeconomics is developed much worse;

- designing of adequate (adaptive) behaviour models of managing subjects (formation of predicted reactions);

- management of transformation and development processes of separate markets and economic system as a whole;

- forecasting of the macroeconomic trajectory of economic system evolution (the theory of institutional changes and evolutionary economy).

However, to achieve these results, aggregated models of the firm and technological changes should be coordinated with the models of institutions modifications. Besides, it is necessary to use microeconomic results of new institutionalism at macro-level of the analysis of economic growth problems (An attempt to create harmonious descriptive institutional theory explaining macroeconomic changes through the changes on micro-level and, in particular, economic growth, was made by Mansur Olson in the book "The Rise and Decline of the Nations" (1982). He linked the change of the number of distributive coalitions in the society with the effect of inhibition of new technologies introduction, that is accompanied by redistribution of resources and braking of economic growth, complicates regulation, increases costs of public administration (Olson, 2013).

\section{Economic growth and technological changes}

Solow's neoclassical model of economic growth, which obtained worldwide fame, is based on the application of production functions machinery. However, Solow perfectly understood (Solow, 1994), that "production function gives an idea about the relationship of the most important factors" (Solow 2007, 1974, 1957). Thus the model does not proceed from the fact that factors interrelation should eventually change and new factors can be added, that 
strictly leads to the necessity of revision of the type of production function used in the growth model. Thereby technological changes refer to the apparatus critics of economic science.

Recently the models including technical changes, education, intellectual capital, trade and other institutionally determined factors as a kind of growth component are the most popular (Alonso-Carrera \& Raurich, 2018; Gabardo et al. 2017; Brancaccio et al., 2018; Iamsiraroj, 2016; Felice, 2016, etc.).

Thus, it is undoubtedly necessary to consider, that past growth occurred under other technological and institutional conditions then present growth, but it is dependent on the previous conditions. Economic growth today is a certain cumulative expression of the past growth (certainly, the authors cannot enumerate all available set of achievements and sources here. See Helpman (Helpman, 2011; Gabardo et al., 2017). For example, in Aghion and Howitt's research (Aghion \& Howitt, 1992) a model is suggested in which Schumpeter's "creative destruction" appears in the form of the appearance mechanism of one innovation for the account of liquidation of the preceding ones.

Innovation appearance is possible not for the account of the reduction of possibilities of last technologies, and sometimes there is even strengthening of the previous model and technological possibilities for the account of the appeared innovation. Technological changes, in general, provide movement of an economic system according to two vectors: wastelessness and unattended operations with simultaneous improvement of management and transactions optimization. Thus such movement occurs under conditions of a technological rush. Baumol (Baumol, 2004) noticed, that "hi-tech firms provoke technological rush as such firms cannot lag behind the competitors. Otherwise, they will lose their market positions".

Influence of institutional factors on economic growth can be specified by the conditions of input and innovation acceptance. This idea developed in the framework of neo-Schumpeter theory, means, that for the innovation to appear, it is necessary not only to have a generator in the form of inventive abilities, entrepreneur's courage, incentive policy of power-holding hierarchies but also and mainly the ability of the environment to accept and disseminate innovation (Nelson \& Winter, 2000). Innovations are presented as change in production functions which cannot be subject to any division. The idea about susceptibility or immunity of this or that innovation visually shows that institutional economy structure can reject innovative development, that is, fixed rules and procedures. In this case, it does not allow creating or appearing intellectual products and their introduction.

Modern economic growth is defined by the level of total productivity of factors which depend on institutional conditions in each country rather than by initial value of income per capita, physical and human capital, educational level, though these parameters are also important. To become a determining condition of steady economic growth not only the rate of capital saving should be rather high, but an increase of technological changes is necessary for the growth rate of income is close to the rate of technological changes. From Solow's model, it follows that the higher the growth rate is, the higher the capital endowments. With the growth of capital intensity the growth rate decreases (Solow, 2007, 1974, 1957). If to explain the conditions providing an increase in total productivity of the factors of growth, then the theory giving such explanations will be the new theory of economic growth. However, the theory explaining the process of technological changes and the development of technologies is also required. It is considered, and it is confirmed by a number of researches, that in the long run total productivity of factors raises owing to investments into research and development: approximately from 10 to $50 \%$ of production growth is the result of growth of research and development, about $40-66 \%$ of growth of total productivity of factors is the result of the growth of research and development (Helpman, 2011; Felice, 2016).

There was also a point of view that the result of technological changes is only a minor improvement of products. However, the effect of research and development is distributed in two directions: products improvement, and creation of new products. These are two purely "consumer" results, but research and development provide knowledge perfection and technological improvements. In the long run, total research and development generate conditions for technological development (sometimes of accelerated dynamics).

The trajectory of scientific and technical development of many countries and the world system as a whole is connected firstly with augmentation of expenses on researches and workings out in the structure of gross domestic product that should be accompanied by quality improvement of the research works and education. Secondly, it is connected with the export expansion of technologies in concrete technological niches which certain states have managed to occupy. And the third reason is the transformation of the niches when their borders become more and more indistinct and the number of technological niches increases. For further effective development, it is important to establish the interaction forms of science, education and economy because these forms will define the dynamics of appearance and use of new knowledge to create specific products and services that will set certain rate of economic growth. As we see from the analysis, the value of research and development expenses itself does not guarantee a high rate of growth even in separate areas of development and does not promote its increase at all. The structure of the economy and institutions, including the organization of technological chains in all directions of the activity, has more value for provision of the steady and high rate of growth. Probably, the value of expenses on research and development and rule creation, that it cannot be less than some value for the economy, are connected with the necessity to provide development of the future growth factors, diligently supporting competitiveness of technologies and technical machinery, but not with the necessity to maintain a certain rate of growth. In other words, such 
investment performs the function similar to the one that blood performs in a human body. The decreasein these expenses will create a shortage of technologies in the long term with the following problems of economic development and dependence on external investments.

To develop the strategies of scientific and technical development of separate countries it is necessary to approximately define the possibility to realize any strategy, at least on the basic parameters.

To achieve this, it is necessary to algorithmize the analysis and to estimate the initial (current, at the moment of consideration) state of economic system objectively, having accepted, for example, the level of three basic indicators for such estimation: 1) resources including natural, physical and human capital; 2) institutional potential including basic institutions, social structure, trajectory of social evolution, mode and way of life, traditions, religious orientation and influence, and etc. (actually this second point defines the trajectory of social development, its stylistics and quality of the institutions which are responsible for social system functioning); 3) scientific-technical and technological potential including fundamental and applied sciences, techniques, technological policy, and current educational level and technical equipment of all processes.

Then we will make up a matrix where lines will mean three major parameters just specified, setting a vector of economic system development and eventually causing the rate of growth (speed of development) for the account of a certain combination of these three parameters which is often unique for each country. Having designated pronounced presence of each parameter separately for the given subject (leadership) as "maturity" or "high level" with sign "+" (It is possible to designate and as 1 (unit), and absence and weak development as zero), and absence of any of them as "-_", we will have a matrix of the state of the subject at the initial stage. It is simplified enough, but useful for the analysis of trajectories of the development, including scientific and technical development. As it is seen from Table 1, there are 8 possible states - strategies of system development (columns) depending on the combination of basic parameters (presence-absence).

Table 1. Trajectories of Economic System Development (Lines are a basic parameter, columns are trajectory potential of scientific and technical development and growth trajectory)

\begin{tabular}{|l|l|l|l|l|l|l|l|l|}
\hline & 1 & 2 & 3 & 4 & 5 & 6 & 7 \\
\hline 1$)$ & + & + & + & + & - & - & - \\
\hline 2$)$ & + & + & - & - & - & - & - & + \\
\hline 3$)$ & + & - & - & + & - & + & + \\
\hline
\end{tabular}

Thus, there are eight models (each model has its own strategy of growth, quality and the trajectory of scientific and technical development. Such simplified classification, nevertheless, is useful at the development of priorities of scientific and technical development and formation of corresponding strategy of the state) of economy development (according to the combination of levels of development/ underdevelopment of basic parameters): model 1 is the ideal trajectory of growth and scientific and technical development when all three parameters have high level and strengthen each other; model 2 is the countries of the Middle East exporting oil, which buy scientific and technical production for the resources, not possessing their own scientific and technical achievements (for these countries institutional potential is not low, they have their own social system based on traditions and religion); model 3 is developing countries where nothing is developed except resources and institutional development potential is low; model 4 is self-sufficient countries according to resources and technological level, but with transitive and unstable regimes, or not efficient institutional system (transitive countries, for example, Russia, separate CIS countries and countries of Eastern Europe); models 5 is the worst standard as opposed to model 1, (conditionally it is possible to take any strongly backward or very poor country for this model, in particular, a country of sub-Sahara Africa with hunger problem); model 6 is a theoretical structure which is probable, but currently there is no vivid example of this model, probably, it is Ukraine, where at rather modest resources unstable institutional structure is all the same combined with the accumulated scientific and technical reserve of the Soviet period; model 7 is Japan, Finland and Sweden which possess modest resources, especially Japan, but high institutional potential of development and scientific and technical potential (recently the experts has called Finland almost the sample of "economy of knowledge". Anyway, in a rating of the countries it occupied the leading positions in second half of 2000s); model 8 is Switzerland and small states, for example, Cyprus and island states specializing on tourism, services, including financial services, with agriculture and very insignificant industry, or without it. They have extremely limited resources. Scientific and technical achievements are absent or are extremely modest, but the institutions' system is stable and supports their specialization in services and tourism industry.

To choose priority directions of scientific and technical development it is necessary to use the method of "achieved", but such method assumes realization of the following principles:

- firstly, the principle of "material provision", estimation of energy, materials, and fixed capital (machines, equipment, and etc.) and financial resources (investments), the latter being especially important;

- secondly, the principle of "non-material provision", characterizing the order of interaction of the system elements, methods of the management system and its elements management, including software and control systems of the processes. 
Being guided by these principles it is easy to consider the basic indicators in the following way: the first indicator, resources, by estimating the reserves of mineral resources, power (generating) capacities, funds, gold exchange reserves, the budget, and etc.; the second basic indicator by estimating social system, political, security, defense and law enforcement, fiscal (monetary) and other institutions; the third indicator by estimating the state and level of education, achievements of science and technology, available accumulated reserves: patents, useful models, inventor's certificates, and etc.

To generate the strategy of economic growth and to define the trajectory of scientific and technical development of the country it is necessary to take some steps.

1. To estimate the current model of economic system functioning (according to the presented matrix).

2. To define the dynamics of change of the basic parameters. Theoretically, on long intervals, the country can move according to the specified models, due to the movement on this or that trajectory (for example, due to the implementation of certain reforms).

3. To designate possible priorities of the development of the given system. To solve the problems of the third step, it is necessary to outline the set of "indisputable" priorities for the concrete system.

4. Estimation of tendencies and risks and working out of scenarios (variants, trajectories) of scientific and technical development.

As a rule, the vectors of scientific and technical development are defined to achieve most often pursued purposes (priorities). They can be the following:

- to achieve power and food independence;

- to provide military priority (defense security, territorial integrity);

- to increase the consumption level and life expectancy of the people,

- to provide ecological, information safety, and etc.

Such purposes cause the necessity of constant perfection of all elements of the system and increase of subject's competitiveness at the world level. But in order to choose the priorities of scientific and technical development, it is necessary to develop the main principles and be guided by them. Some of them are presented below.

A. Definition of perspective sectors and kinds of activity (basic branches) and directions of activity to achieve each of the purposes which are set for the system (definition of the technological core).

B. Choice of key technologies, know-how and technological decisions, putting these sectors and kinds of activity and direction to the leading world positions according to point A (determination of some technologies and their cores which will make the nearest and remote prospect).

C. Making up of the list of the accompanying technologies which are not the key ones (in contrast to point B), but obligatory at the given stage of development to achieve the purposes (definition of the periphery and the ways of its perfection).

G. Comparability of the expected result of the purpose achievement and the expenses for its achievement, registration of alternatives and inertia of the competing systems development.

D. Constant monitoring of external conditions to acknowledge the urgency of the purposes for timely updating of priorities and maintenance of application area of efforts and functional variety at the due level necessary for steady economic growth.

Realization of the specified principles with the help of which it is possible to build the trajectory of scientific and technical development assumes estimation of the reasons of change of the demand for these or those technologies, analysis of technological economy structure developed by the current moment (diagnostics). It is possible to single out three main "reasons" of the demand for technologies: 1) human vital activity and the basic needs (biological, physical, cultural, and etc.); 2) protection of the nature and the society against external threats cataclysms, ecology, climate change, wars, conflicts, space, and etc.; 3) cognition of the surrounding world (micro and macro world).

Deep down, these three directions of the demand for technologies cause both appearance and development and perfection of technologies. In this connection, the process of technologies appearance, which is still poorly described by economic science, is presented in three ways which can be manifested separately or can be somehow combined.

Firstly, "heuristic" way of technologies appearance when absolutely new technologies appear owing to certain discovery, invention, the creation of new material, mechanism and device. The frequency of such events is reduced, that is, "epoch-making" events seldom occur.

Secondly, "incremental" way of technologies development when after "epoch-making" events there is improving perfection of the known technologies and traditional ways of production that provides efficiency increase.

Thirdly, "combinatory" way of technologies development when new technologies appear, or traditional ones are improved owing to parallel and consecutive combination of separate technologies. Thus big investments are not necessary and new epoch-making discovery should not be expected. "Combinatory" principle does not reject the principle of "creative destruction" on which the majority of modern models of technological development are based, but, on the contrary, it underlines the development specificity of modern techniques and new technologies when the resource cannot be borrowed from previous combinations and there is a necessity to create it for a new combination in the economy. Thereby the effect of multiplication on new combinations in the economy has quite a different basis 
connected with the process of creation and development of techniques and technologies. From this point of view, the multiplication effect of new combinations depends on the state of scientific and technical personnel and conditions of research work, but not only and not so much on the finance. Considering these facts, the importance of the current economic structure and its efficiency sharply increases. But it is also impossible to increase the efficiency of such initial structure without due financing. If having financed a new combination, money is put into circulation, and the combination is created for a certain period of time, inefficient structure can transform money increment into amplifying inflationary pressure which will increase the costs of this new combination and will create the necessity of additional financing which will be impossible to provide because of unforeseen changes, increase in prices and percent.

A variety of technologies and a large number of combinations on the interfaced technologies and even technologies, which seem to be not connected in any way with each other (from different kinds of activity), nevertheless, can provide important combinatory combinations which will result not only in efficiency increase of the given technologies class, but also will expand other technological possibilities, replacing "heuristic" class of technologies.

\section{Institutions and economic growth}

Unfortunately, the majority of economic growth models does not consider both the influence of many institutions on economic growth, and does not pay attention to the changeability of these institutions, and influence this very factor on the rate of economic growth. On the one hand, from the formal-mathematical position, it is not obviously possible to consider the "content" of the institution and its influence. On the other hand, the functioning of any institution can be treated from the position of its influence on some parameters which will characterize product change in the course of time (either growth or reduction). The institutions which are responsible for production, consumption, exchange, blessings distribution and institutions of economic policy and political system will define the possibilities of economic growth. The question is how their integrated influence will be formed. At the same time, separate institutions, such as the revenue code, will influence economic growth more strongly, than individual habits of consumption of separate blessings. Thus, it is changed in these strong institutions that will be the determining factor of growth. For each economic system, there is its own set of such "strong" and "weak" norms.

Under conditions of economic growth, there is one system of factors interrelation, including the dependence of the countries. At the recession, another combination of these factors is observed. And they can be reorganized so, that they have different meaning relative to the growth. This property is reflected neither in known models nor in the descriptions and reviews on the theme "economic growth". We will tabulate the data which economic science has received for today regarding the explanation of institutional factors of growth in Table 2. Separate factors of economic growth are designated in the left column, and their characteristic, proceeding from the available ideas about their influence, are presented in the right column.

As we see, the same factor can promote growth, or, under other conditions, brake it. How the whole set of causes influences total productivity remains not quite clear, therefore the new theory of economic growth should clear up such questions.

Table 2. InstitutionalFactors of Economic Growth (the table was created by authors)

\begin{tabular}{|c|c|}
\hline $\begin{array}{c}\text { Institutional } \\
\text { Factor }\end{array}$ & Features of Impact on Economic Growth \\
\hline $\begin{array}{l}1 . \\
\text { Assets } \\
\text { (Physical } \\
\text { Capital) }\end{array}$ & $\begin{array}{l}\text { Accumulation process influences economic growth greatly. The first and the following models of growth made a start from this } \\
\text { position - influence of the rate of saving (fixed capital in Gross Domestic Product) and the rate of the economy (value of non- } \\
\text { consumed Gross Domestic Product - economy of Gross Domestic Product). Funds relative to growth models are not the same, as } \\
\text { technologies. Funds are a condition of growth and thus they define the rate of growth, the speed of change of Gross Domestic } \\
\text { Product, as productivity of the equipment and labour depends on the funds. Certainly, technological changes transform the funds } \\
\text { and change the character and quality of skilled and unskilled labour, that is, composition (structure) of labour. }\end{array}$ \\
\hline $\begin{array}{l}2 . \\
\text { Human } \\
\text { Capital }\end{array}$ & $\begin{array}{l}\text { Human capital is represented by knowledge received through education, continuing professional development and retraining } \\
\text { which should be expressed in the monetary form (cost form), that is a problem in itself. Sometimes human capital is explained as } \\
\text { an investment into knowledge acquiring, getting certain qualification and maintenance of health level, that is, achieving some } \\
\text { function value of qualification and health. In this case, human capital is proportional to the investments for these purposes and } \\
\text { depends on the value of state expenses on education and public health services. Presence of physical and human capital at the } \\
\text { given level of natural-resource capital is a necessary condition of growth. }\end{array}$ \\
\hline $\begin{array}{l}3 . \\
\text { Innovations, } \\
\text { Research and } \\
\text { Development }\end{array}$ & $\begin{array}{l}\text { A steady flow of innovations, a model of growth with inventive activity, a disaggregated model of knowledge instead of } \\
\text { aggregated, investments into research and development plus institutions - patents, the legal system, trademarks, trade and foreign } \\
\text { investments. The higher the rate of savings is, the higher is the share of investment into research and development is, innovators, } \\
\text { obtain monopolistic power and additional profit that increases investments into research and development and expands the } \\
\text { assortment of products. The number of engineers and research and development influence the rate of growth which raises with } \\
\text { their growth. Knowledge creates a positive externality. }\end{array}$ \\
\hline
\end{tabular}


End of Table 2

\begin{tabular}{|c|c|}
\hline Institutional Factor & Features of Impact on Economic Growth \\
\hline $\begin{array}{l}4 . \\
\text { Investments }\end{array}$ & $\begin{array}{l}\text { Investments were included in the very first models of economic growth. There is no modelling of economic } \\
\text { growth without them. For high stakes, all theories of growth and models are "investment". If the factor of growth } \\
\text { does not have due financing, it will not be involved in blessings production. At least, its functions will be } \\
\text { evidently narrowed. However, modern economic growth is not defined by the volume of gross or net investments } \\
\text { so much, but by the structure of investments, that is, by how they are distributed between the factors composing } \\
\text { total productivity. Change of the investment stream structure will define economic growth greatly. }\end{array}$ \\
\hline $\begin{array}{l}5 . \\
\text { Technologies of Various } \\
\text { Kinds and Wide } \\
\text { Application }\end{array}$ & $\begin{array}{l}\text { Pulsating flow of innovations and technological changes owing to the development of technologies of wide } \\
\text { application (steam-engine, electricity, computers, telecommunication technologies, and etc.). The number of } \\
\text { engineers and research and development influences increase in total productivity of factors not so strongly. Model } \\
\text { of assortment expansion on quality on the basis of the principle of "creative destruction", when high-quality } \\
\text { products supersede poor quality. The abilityto master foreign technologies (adsorption) is different. }\end{array}$ \\
\hline $\begin{array}{l}6 . \\
\text { Terms of Trade }\end{array}$ & $\begin{array}{l}\text { Trade can stimulate or slow down economic growth. International trade does not lead to convergence in the } \\
\text { growth of different countries and world regions. The structure of demand and primary knowledge strongly } \\
\text { influence the result of exchanges. The established rules of trade influence in the same way. Protectionism can } \\
\text { promote technological changes, as well as the opening of the economy to accelerate the growth of total } \\
\text { productivity of factors. }\end{array}$ \\
\hline $\begin{array}{l}7 . \\
\text { Distributive Coalitions }\end{array}$ & $\begin{array}{l}\text { The increaseof distributive coalitions brakes technological changes increases the growth of regulation costs and } \\
\text { slows down growth. Olson's concept claims for the status of the theory explaining the ups and downs of different } \\
\text { countries. }\end{array}$ \\
\hline $\begin{array}{l}8 . \\
\text { Education }\end{array}$ & $\begin{array}{l}\text { Economic growth on the basis of the learning model, a model of higher productivity for the account of human } \\
\text { capital growth; the rate of saving is proportional to the resource of human capital. The effect of learning (in } \\
\text { institutional sense) can slow down economic growth owing to three reasons: 1) productivity declines at training; } \\
\text { 2) time is necessary to create the resource for new combination that will also slow down growth; 3) innovations } \\
\text { can become the factor of economic growth slowdown (at financial system disbalance) If the model of } \\
\text { accumulation of human capital extending boundlessly (according to Lucas) is in the basis of growth model, the } \\
\text { economy will always grow faster than the rate of technical progress. }\end{array}$ \\
\hline $\begin{array}{l}9 . \\
\text { Public Health }\end{array}$ & $\begin{array}{l}\text { Institutional forms of public health will define the value of investments into this sphere that will define life } \\
\text { expectancy of the population, population growth and preservation of labour activity. Hence, this factor is, in } \\
\text { essence, a part of the factor "human capital", but human capital is not homogeneous, as well as the state of basic } \\
\text { institutions which are responsible for education and public health functioning. Therefore, it is, probably, logical to } \\
\text { divide this kind of capital into subspecies and to complicate the production function and economic growth } \\
\text { models. In other words, economic growth models should be improved towards taking structural and institutional } \\
\text { features of construction and development of the economic system into account. }\end{array}$ \\
\hline $\begin{array}{l}10 . \\
\text { Institutions, Including } \\
\text { Historical Conditions, } \\
\text { Law, and Economic Policy }\end{array}$ & $\begin{array}{l}\text { Fundamental growth determinants specify stimulus to innovations and agents' possibilities (adaptation). } \\
\text { Institutions change and generate three groups of effects: } 1 \text {. Effect of the market scale; } 2 \text {. Effect of competition; } 3 \text {. } \\
\text { Decontrol, privatization and liberalization. Investments into innovations, depending on the functioning mode of } \\
\text { the institutions, lead to increase of rupture between rich and poor. }\end{array}$ \\
\hline $\begin{array}{l}11 . \\
\text { Inequality and the Current } \\
\text { Economy Structure }\end{array}$ & $\begin{array}{l}\text { Growth on the basis of "Kuznets' hypothesis (curve)" which does not have strict confirmation on } \\
\text { various economic systems. In the countries with low incomes per head, inequality growth will lower } \\
\text { the rate of growth, in countries with high incomes the rate of growth will grow (Barro condition for a } \\
\text { certain time interval). This dependence does not always remain as well as the Kuznets curve. } \\
\text { Inequality can influence economic growth, however, there is no strict connection here. Everything is } \\
\text { defined by the initial state, historical conditions, and the level of technologies development. If in the } \\
\text { West the period of rapid industrialization was accompanied by income growth and stratification } \\
\text { growth according to the income level (inequality), it is hardly appropriate to say, that growth was } \\
\text { carried out for the account of inequality. It is incorrect. In general, paired consideration of factors } \\
\text { withdraws far from the true understanding of economic growth conditions. The economy's structure } \\
\text { is a more important condition of growth, than inequality in income distribution. If it has developed, } \\
\text { basically economic growth is possible in the nearestperspective for the account of this structure. }\end{array}$ \\
\hline $\begin{array}{l}12 . \\
\text { Interdependence of the } \\
\text { Countries }\end{array}$ & $\begin{array}{l}\text { Economic growth of one country can affect the growth of other countries, and the measure of } \\
\text { influence will be defined by many reasons, mainly, institutional and structural. In this case, factors } \\
\text { are reconstructed in an even more unpredictable way, than in other cases. Researches should define } \\
\text { the object and the factor precisely. For example, trade liberalization can strengthen growth, and can } \\
\text { essentially lower the rate of economic growth owing to the concrete mode of interdependence. }\end{array}$ \\
\hline
\end{tabular}

Let us, for example, consider the factor of "terms of trade". It usually includes the openness and closedness mode (protectionism and free trade), transfer of technologies, borrowing, and etc. Economy openness will lower the price for the production of the products of which requires considerable human capital. This change should lead to a price reduction for human capital, lower expenses on research and development, increase the profitability of investments into research and development and their volume. Thus, it will give growth to the volume of research and development, increase the productivity of factors and the rate of growth (Helpman, 2011). That is a relationship between institutional parameters designated in the table. But, if any factor with big "power" appears in the specified 
chain of changes, for example, low effective conditions of granting of credit, then the price for human capital can increase. It will increase expenses on research and development, and reduce investments into research and development. The outcome will be a decrease in the total productivity of production factors if other factors do not "pay off" this decrease and decrease in the rate of economic growth.

Interdependence of the countries is an easily explainable phenomenon, though poorly studied. Thus, if there is economic growth in one country (A), it is manifested in the growth of the demand for some resources. In case, when country A approaches to a threshold of their exhaustion, or considerable growth of extraction costs, and extraction and transportation from country B is cheaper, country A demonstrates demand for the resource of country B. The price of the resource increases. In response, the supply of this resource also increases a little if there are available reserves (either on extraction or on stocks). Imagine, that economic growth of country A requires some set of resources $r=\left\{r_{1}, r_{i}, \ldots . r_{n}\right\}$, but not all of these resources can be provided by country $B$. Then in similar situations, demand will increase not only for resource $\mathrm{r} 1$, but also for resource $\mathrm{r}_{i}$ which is provided by country $\mathrm{C}$, if it is absent in country A, or consumption is saturated. In that case, growth in country A pulls the growth of corresponding resources in other countries as a locomotive. Their extraction or production grows if certain parts or production components are meant as a "resource". Certainly, it is not at all a fact, that the rate of growth will increase in these countries. It can be only structural change when the production of one certain resource has increased. However, with general growing tendency in a number of countries and due to greater international cooperation and trade this effect can capture a considerable part of the economy of interconnected countries. It will exceed negative effects with the terms of trade which were discussed above and will provide general dynamics of growth. It is important to consider here what the generator of growth at the interdependence of the countries is, and what the direction of the dependency vector is: one country can depend on A more strongly, the other - less. Besides, country A can be dependent on the first country according to the development of separate spheres and does not depend on the second one and so on. These circumstances are the most important things while studying modern problems of economic growth. The analysis of such conditions can make the strategy of catching up/advancing growth for some countries senseless, as the force of structural dependence connects the possibility of growth acceleration to the rate of growth of other countries (leaders). If such "connection" has already developed and there is an obvious leader - the locomotive of world economic growth even if this country does not occupy the leading position according to the absolute development indicators and living standard, the question when it becomes such leader is only the question of time, provided it sets the mode of world growth and if there are no serious institutional changes.

Management of the economy effects greatly on the growth because it directly influences the component change of Gross Domestic Product - aggregate consumption, gross investments, government expenditures and net export. If we compare this new product with the product of the previous period in per cent for the same time unit, usually a calendar year, the rate will be the same as the change of these parameters and the increase of Gross Domestic Product. Thus, the introduction or easing of customs procedures (customs duties) will affect net export, but it can influence technologies transfer and research and development. Such actions can influence the rate of growth. Thereby instrumentalization of the growth models occurs from the most general, aggregated, macroeconomic models (as Harrod's model and others) disaggregated with the division of production function to define the sensitivity of governmental tools influencing economic growth.

Interdependence of the countries will influence the rate of economic growth in each country, but this interdependence is provided by the terms of trade, investments, technologies transfer, cooperation in the field of science and techniques, joint researches and development, programs of training and corporate cooperation and other institutions. The more widely is the scale of such interaction and large-scale the contracts concluded, the higher the long-term rate of growth of income per capita will be. As Helpman marks, proceeding from the resulted review, international trade does not necessarily bring together the rates of growth of interconnected countries and does not necessarily result inahigher rate of growth in many connected countries (Helpman, 2011). The effect of the country's scale is expressed in the impact on the level of income which the country reproduce at the given mode of trade (protectionism level and trade liberalization). Hence, various researches lead to opposite conclusions that tell in favour of my position, that factors change the force and weight towards economic growth, but it is practically impossible to define the law of this change. It is not necessary to absolutize trade like an institutional factor of growth, because "stronger" factors operate in the form of institutional reforms and cumulative high-speed institutional changes. Besides, technologies and macroeconomic policy will define the mode of international trade for the given country. Inequality level and the schemes of distribution of created income can be much stronger, than the trade of the product already made.

In other words, mathematically the theory of growth can be quite acceptable, but it will not be a working theory until the relationship logic explained taking into account the change of factors weight varying in the process of economic growth on the significant time interval. It is important to establish how and why the weight of these factors will change. In the economy, first, one factor and then others will gain strength. 


\section{Conclusions}

Thus, it is difficult enough or almost impossible, if to be exact, to divide institutional factors of economic growth. However, some influence of institutional factors on the rate of economic growth can be estimated as follows.

Firstly, the rate of economic growth has been determined by the rate of population increase strongly enough. If population growth is slowed down, as it follows according to some forecasts, it will also decelerate economic growth. These conclusions can have no confirmation in the modern economy, where the rate is ensured by information, knowledge and technological rush.

Secondly, the rate of growth depends on the level of the "living standard" by the given moment, the speed of incomes change of the least secured group of the population and the speed of change of intellectual capital. The greater these values are, the higher the overall growth rate of income. However, the more the information volume, that is, the more is the change of information processed by the agent in the time unit, the lower the growth rate will be.

Thirdly, institutional conditions of economic growth which can be reduced to agents' reactions to changes and to influence of average speed of changes (it is clear, that the change of each institution is unique as the content of one institution differs from the content of the other institution), can affect growth in the following way: the higher the sensitivity and the speed are, the lower the rate of growth will be with very high probability. At high sensitivity the agents simply reject the changes of institutions, transactional costs rise and, their benefits grow more slowly.

It is shown how a scientifically based strategy of economic growth should be built (an algorithm to formulate decisions within the framework of economic growth policies is proposed), taking into account the emerging types of growth regimes, when the economic system detects different dynamics, going from one state determined by one set of factors and conditions another, already with a different set of factors and conditions. In addition, a set of factors may persist for some impressive period of time, but here the weights, that is, their significance, change. The role of technology and institutions in influencing economic growth has been investigated, as well as models of economic policy, a system growth model has been proposed, which allows decomposing the impact of a number of factors, defining types of policies for changing growth strategies. A useful algorithm has been defined to substantiate a science and technology policy that meets the level of existing and developed growth factors in order to enhance the economic dynamics by improving the technological effectiveness of the system, ensuring proportionality of the influence of technologies and institutions on the growth rate.

It is proved that the increase in the technological level of the economy is possible due to the increase of results in the field of used (old) and the use of new technologies. However, over the considered time interval, the number of advanced production technologies decreased by a quarter. In the processing industries, there is a general loss of advanced technologies with an increase in the number of developed advanced technologies. If this continues, there will be a 2 -fold decrease in the number of technologies over the next 8 years. Consequently, the key goal is to increase the overall adaptability of the economic system with a common vector for the appropriate distribution of investment between the old and new technological capabilities. This fundamentally clarifies the algorithm for the formation of national development priorities. In essence, a theoretical justification is given with the necessary empirical verification that the old technologies, which are also substantially underdeveloped, require assignment to the priority areas of development. Directing resources only to the field of new technologies can dramatically increase the imbalances in the development of the economic system, although this does not mean abandoning such prioritization. Hence, institutional reforms can often decelerate economic growth regardless of the incentive motives of the carrying out. The technological level of the economy will also be an indicative factor here defining economic dynamics together with the changing institutions.

Like every study in economic sciences, this study has the following limitations.

1. The model developed in the study is based on the survey of literature carried out for the present study. The research model is limited to study of economic growth and technological changes, it is recognized that a number of other constructs have been included in the study to make it more appropriate to the fast technological development.

2. A further limitation is that the study findings may not be applicable across different economic and political settings; researchers may find that results differ from one state to another one.

\section{Directions for future research}

The outcomes of this research may enrich an economic theory and practice in the area of business models applicability. The findings may assist a business community to influence the general technological development within the national institutional systems.

1. Specific research directions include identifying whether economic growth models and/or technological changes can be used in order to identify the possible directions of economic development.

2. Further investigation of the relation between the development of economic growth and a type of technological development, can be undertaken. 


\section{Acknowledgements}

The authors would like to express their deepest appreciation to all those who provided us with the possibility to complete this research. Special gratitude we give to Professor Olga Leonidovna Rogova (deceased) and Professor Galina Nikolaevna Beloglazova (deceased), whose contribution in stimulating suggestions and encouragement, helped us to complete this paper.

\section{References}

Aghion, P., \& Howitt, A. (1992). Model of Growth through Creative Destruction. Econometrica, (2), $323-351$. https://doi.org/10.2307/2951599

Aguirre, A. (2017). Contracting institutions and economic growth. Review of Economic Dynamics, 24, $192-217$. https://doi.org/10.1016/j.red.2017.01.009

Alonso-Carrera, J., \& Raurich, X. (2018). Labor mobility, structural change and economic growth. Journal of Macroeconomics, 56, 292-310. https://doi.org/10.1016/j.jmacro.2018.03.002

Balachandran, B., \& Williams, B. (2018). Effective governance, financial markets, financial institutions \& crises. Pacific-Basin Finance Journal, 50, 1-15. https://doi.org/10.1016/j.pacfin.2018.07.006

Bartolini, D., \& Santolini, R. (2017). Political institutions behind good governance. Economic Systems, 41(1), 68-85. https://doi.org/10.1016/j.ecosys.2016.05.004

Baumol, W. (2004). Red-Queen games: arm races, rule of law and market economies. Journal of Evolutionary Economics, 14(2), 237-247. https://doi.org/10.1007/s00191-004-0207-y

Blaug,M. (1994). Economic Thought in retrospective review. Moscow: Business.

Brancaccio, E., Garbellini, N., \& Giammetti, R. (2018). Structural labour market reforms, GDP growth and the functional distribution of income. Structural Change and Economic Dynamics, 44, 34-45. https://doi.org/10.1016/j.strueco.2017.09.001

Cantner, U., \& Hanusch, H. (2002). Evolutionary economics, its basic concepts and methods. A tribute to Mark Perlman, Editor of the Journal of Evolutionary Economics 1991-96. In H. Lim, U. K. Park, \& G. C. Harcourt (Eds.), Editing Economics. Essays in honor of Mark Perlman (pp. 182-207). London: Routledge. https://doi.org/10.4324/9780203472200

Coase, R. (1993). The firm. The market. The law. Moscow: Business.

Coase, R. (2000). Interview at the Founding Conference of International Society of New Institutional Economy. St. Louis, 1997 September $17^{\text {th }}$. Quarterly Bulletin of Economists Club, 4, 1-28.

Felice, G. (2016). Size and composition of public investment, sectoral composition and growth. European Journal of Political Economy, 44, 136-158. https://doi.org/10.1016/j.ejpoleco.2016.07.001

Gabardo, F. A., Pereima, J. B., \& Einloft, P. (2017).The incorporation of structural change into growth theory: A historical appraisal.Economia, 18(3), 392-410. https://doi.org/10.1016/j.econ.2017.05.003

Hartwell, C. A. (2016). The institutional basis of efficiency in resource-rich countries. Economic Systems, 40(4), 519-538. https://doi.org/10.1016/j.ecosys.2016.02.004

Helpman, E. (2011). The mystery of economic growth. Moscow: Publishing House of E. T. Gaidar Institute.

Hodgson, J. (2003). Economic theory and institutions. Moscow: Business.

Hodgson, J. (2006). Evolutionary and Institutional Economy as New «Mainstream»?. Economic Bulletin of Rostov State University, 6(2), 8-21.

Homan, P. (1932). An appraisal of institutional economics. American Economic Review, 22(1), 10-17. Retrieved from https://www.jstor.org/stable/1807255

Iamsiraroj, S. (2016). The foreign direct investment - economic growth nexus. International Review of Economics \& Finance, 42 , 116-133. https://doi.org/10.1016/j.iref.2015.10.044

Lucas, R. (1981). Studies in business-cycle theory. MIT Press.

Menard, C. (1996). Economy of organizations. Translation from French. Moscow: Infra-M.

Nelson, R. (2008). Economic development from the perspective of evolutionary economic theory. Oxford Development Studies, 36(1), 9-21. https://doi.org/10.1080/13600810701848037

Nelson, R., \& Winter, S. (2000). Evolutional theory of economic changes. Moscow: Finstatinform.

North, D. (2010). Understanding of the process of economic changes. Moscow: Publishing house GU Higher School of Economics.

Olson, M. (2013). Eminence and decline of the nations. Economic growth, stagflation and social sclerosis. Moscow: New Publishing house.

Ryser, L., Halseth, G., Markey, S., \&Morris, M. (2016). The structural underpinnings impacting rapid growth in resource regions. The Extractive Industries and Society, 3(3), 616-626. https://doi.org/10.1016/j.exis.2016.06.001

Samaniego, R. M., \& Sun, J. Y. (2016). Productivity growth and structural transformation. Review of Economic Dynamics, 21, 266-285. https://doi.org/10.1016/j.red.2015.06.003

Silverberg, G., \& Verspagen, B. (1995). Evolutionary theorizing on economic growth. Discussion paper. MERIT, Maastricht.

Solow, R. (1994). Perspectives of the theory of growth. Journal of Economic Perspectives, 8(1), 45-54. https://doi.org/10.1257/jep.8.1.45 
Sukharev, O.; Chaplygin, V. 2019. Economic policy of growth: selection of institutes and technological models of development

Solow, R. M. (1957). Technical change and the aggregate production function. Review of Economics and Statistics, 39(3), 312320. https://doi.org/10.2307/1926047

Solow, R. M. (1974). The Economics of Resources or the Resources of Economics. The American Economic Review, 64(2), 1-14. https://doi.org/10.1057/9780230523210_13

Solow, R. M. (2007). The last 50 years in growth theory and the next 10. Oxford Review of Economic Policy, 23(1), 3-14. https://doi.org/10.1093/oxrep/grm004

Veblen, T. (1980). The theory of idle class. Moscow: Progress.

Veblen, T. (2007). The theory of the business enterprise. Moscow: Business.

Vo, L. V., \& Le, H. T. T. (2017). Strategic growth option, uncertainty, and R\&D investment. International Review of Financial Analysis, 51, 16-24. https://doi.org/10.1016/j.irfa.2017.03.002

Williamson, O. (1975). Markets and hierarchies. N.Y.: Prentice-Hall.

Yang, H., \& Jung, W.-S. (2016). Structural efficiency to manipulate public research institution networks. Technological Forecasting and Social Change, 110, 21-32. https://doi.org/10.1016/j.techfore.2015.12.012 